ГОРДЕЕВА-ГЕРАСИМОВА

Людмила Юрї̈на

gor.luda@gmail.com
УДК 657

\section{ОБЛІК У БЮДЖЕТНІЙ СФЕРІ: ПРОБЛЕМИ СЬОГОДЕННЯ}

стариий викладач, Дніпровський

\title{
ACCOUNTING IN THE BUDGETARY SECTOR: PROBLEMS OF TODAY
}

національний університет

ім. Олеся Гончара

\section{HORDIEIEVA-HERASYMOVA Liudmyla Yuriivna - Senior Lecturer, Dnipro National University after Oles Honchar}

У статті розглянуто результати реформування обліку бюджетної сфери. Позитивним є те, щзо розроблені національні стандарти бухгалтерського обліку в державному секторі, які узгоджено з міжнародними, новій, уніфікований план рахунків бухгалтерського обліку в державному секторі, підвищено рівень прозорості та відкритості ведення бухгалтерського обліку складання фінансової звітності. Але ще існують певні проблеми. Вони стосуються необхідності удосконалення системи підготовки та перепідготовки кадрів з обліку, і також інформаційно-аналітичної системи ведення бухгалтерського обліку та складання фінансової звітності в бюджетній сфері.

$$
* * *
$$

В статье рассмотрены результаты реформирования учета бюджетной сферы. Положительным является то, что разработаны начиональные стандарты бухгалтерского учета в государственном секторе, которые согласованы с международными, новой, унифицированный план счетов бухгалтерского учета в государственном секторе, повышен уровень прозрачности и открытости ведения бухгалтерского учета, составления финансовой отчетности. Но ешее существуют определенные проблемы. Они касаются необходимости совершенствования системы подготовки и переподготовки кадров по учету, а так же информационно-аналитической системы ведения бухгалтерского учета и составления финансовой отчетности в бюджетной сфере.

$$
* * *
$$

Introduction. Currently, integration processes in the European and world community are underway in Ukraine. In this regard, the alignment of national accounting and financial reporting methodology in the public sector to international standards is a prerequisite for the implementation of Euro-integration processes. It is promotes effective analytical activities, enhances transparency of budgetary use, targeted use of borrowed funds.

The purpose of paper is a study of theoretical and practical provisions of the organization of accounting in the budgetary sector, implementation of its reform and reflection of modern problems of its improvement.

Results. Budgetary institutions are one of the relevant links in the budgetary sector. Accounting and financial reporting in them is determined by the legislation on the budget, the budget system, the basis of budget policy; appropriate public sector accounting guidance; other normative documents of the Ministry of Finance of Ukraine and the State Treasury Service of Ukraine.

In the process of reform accounting in the budgetary sector, national public sector accounting standards have been developed that are consistent with international ones. A new, unified, public sector accounting plan has been built, and the level of transparency and openness of accounting has been improved.

However, problems in the accounting and reporting system of public sector institutions remain. There is a need for final adaptation of the Ukrainian legislation on accounting and financial reporting to international requirements and compliance with changes in regulatory regulations; creation and implementation of an effective information and analytical accounting system and preparation of financial statements by public sector entities..

Conclusion. It is necessary to: improve the system of training and retraining of personnel of accounting and financial profile in the public sector, informational and educational support on measures of reforming the accounting of the budgetary sector, as well as introduction of an effective information system of accounting.

Further adaptation of accounting in the budgetary sector to international standards promotes transparency in the management of public finances and allows to create a unified organizational and information support of accounting in the budgetary sector.

Ключові слова: облік, бюджетна сфера, державний сектор, Національні положення (стандарти) бухгалтерського обліку в державному секторі, план рахунків, звітність, реформування

Ключевые слова: учет, бюджетная сфера, государственный сектор, Национальные положения (стандарты) бухгалтерского учета в государственном секторе, план счетов, отчетность, реформирование, модернизачия

Keywords: accounting, public sector, budgetary sector, National regulations (standards) for public sector accounting, an account plan, reporting, reform, modernization

\section{ВСТУП}

В умовах сьогодення ми можемо спостерігати активні процеси соціально-економічного та господарського розвитку, які супроводжуються глобальними змінами у світовій фінансовій системі. Вони відбуваються за участю або під егідою найавторитетнішої і загальновизнаною організацією, що об'єднує органі- зації всього світу - ООН. Світовий простір загалом, i європейський особливо, стають все більш відкритими для злиття капіталів, фінансових і товарних потоків; для обміну інформацією, знаннями та ідеями, студентами, викладачами, фахівцями, туристами, дипломатами.

Відповідні інтеграційні процеси в європейське і світове співтовариство здійснюються і нашою державою. Про це свідчить підписання Угод про вступ до 
СОТ, про асоціацію з СС, про надання безвізового режиму тощо. Їх імплементація входить у зобов'язання країни стосовно виконання Плану заходів у рамках Меморандуму про взаєморозуміння між Україною, як боржником і Свропейським Союзом, як кредитором $[3$, с. 5$]$.

Однієї із умов євроінтеграції було приведення у відповідність національної методології бухгалтерського обліку та фінансової звітності у державному секторі до міжнародних стандартів. Що повинно сприяти організації ефективної аналітичної діяльності, посилення прозорості використання бюджетних коштів, цільового використання залучених кредитних ресурсів, особливо закордонних.

\section{МЕТА РОБОТИ}

Метою дослідження є дослідження теоретичних та практичних положень організації обліку у бюджетній сфері, здійснення його реформування та відображення сучасних проблем його удосконалення.

\section{МЕТОДИ ДОСЛІДЖЕННЯ}

Методологічною та інформаційною основою роботи є наукові праці, матеріали періодичних видань, pecyрси Internet. Під час проведення дослідження були використані наукові методи аналізу, синтезу, порівняння та узагальнення.

\section{РЕЗУЛЬТАТИ}

Однією із відповідних ланок бюджетної сфери $є$ бюджетні установи, які, згідно з Бюджетним кодексом України, розуміються як органи державної влади, органи місцевого самоврядування, а також організації, створені ними у встановленому порядку, що повністю утримуються за рахунок відповідно державного бюджету чи місцевого бюджету. Бюджетні установи $є$ неприбутковими [2]. Ведення бухгалтерського обліку та фінансової звітності у них визначається законодавством про бюджет, бюджетну систему, основу бюджетної політики; відповідними інструкціями з бухгалтерського обліку в державному секторі; іншими нормативними документами Міністерства фінансів України та Державної казначейською службою України. Доцільно відмітити, що органи, які здійснюють створення та перерозподіл бюджетів усіх рівнів, є бюджетними установами, які виконують відповідні функції в рамках своїх повноважень.

Відповідно до сфери діяльності, бюджетний облік поділяється на бухгалтерський облік виконання бюджетів та бухгалтерський облік виконання кошторисів бюджетних установ. Згідно 3 положеннями Бюджетного кодексу України, бухгалтерський облік виконання кошторисів бюджетних установ ведуть розпорядники бюджетних коштів, а бухгалтерський облік виконання державного і місцевих бюджетів - органи Державної казначейської служби України. Органи Державного казначейської служби України ведуть бухгалтерський облік операцій за касовим виконанням державного та місцевих бюджетів за доходами у розрізі видів надходжень і органів стягнення, а за видатками - у розрізі напрямів й економічної сутності витрат і розпорядників коштів бюджетів.

До специфічних особливостей організації бюджетного обліку в Україні слід віднести: контроль викона- ння кошторису доходів та витрат; окремий облік касових і фактичних витрат; організацію обліку у розрізі статтей бюджетної класифікації.

На даний час облікова система установ державного сектора знаходиться у стані реформування. Зроблено вже дуже багато. Урядом України було прийнято ряд нормативних документів, які стали підгрунтям для здійснення процесу реформування, а саме «Стратегія модернізації системи бухгалтерського обліку в державному секторі на 2007-2015 роки» [7], «План заходів щодо модернізації системи бухгалтерського обліку в державному секторі на 2016-2018 роки» [4], «Стратегія модернізації системи бухгалтерського обліку в державному секторі на 2018-2025 роки» [5] та «Стратегії реформування системи управління державними фінансами на 2017-2020 роки» [6], за результатами втілення положень яких були розроблені та впроваджені:

- Національні положення (стандарти) бухгалтерського обліку у державному секторі (НП(С)БОДС) на основі Міжнародних стандартів бухгалтерського обліку для державного сектору (МСБОДС);

- новий єдиний Плану рахунків бухгалтерського обліку у державному секторі (надалі - План рахунків), який може використовуватись як в обліковому процесі бюджетних установ, державних цільових соціальних фондів, так і органами Державної казначейської служби України в процесі обслуговування Єдиного казначейського рахунку;

- нові форми фінансової звітності в обліку державного сектору;

- підвищено рівень прозорості та відкритості ведення бухгалтерського обліку завдяки впровадженню НП(С)БОДС.

Водночас проблеми у системі бухгалтерського обліку і звітності установ державного сектора економіки, які саме визначили необхідність проведення реформи системи бухгалтерського обліку, на жаль, ще залишаються. Насамперед, мова йде про необхідність остаточної адаптації законодавства України з питань бухгалтерського обліку та фінансової звітності до міжнародних вимог, адже міжнародні стандарти теж змінюються, і це треба враховувати; також існує потрібність у подальшому вдосконаленні системи бухгалтерського обліку в держаному секторі у відповідності до змін регулюючих нормативно-правових актів; удосконаленні системи підготовки та підвищення кваліфікації працівників бухгалтерських служб бюджетний установ; створенні та впровадження ефективної інформаційно-аналітичної системи ведення бухгалтерського обліку та складання фінансової звітності суб'єктами державного сектору.

Крім того, важливе значення має інформаційна та освітня підтримка стосовно впровадження стандартів, тобто організація навчання з питань застосування стандартів, проведення конференцій, практичних семінарів для фахівців-бухгалтерів 3 обліку в бюджетній сферi [5-6].

Також позитивним в реформуванні можна вважати те, «що під час реалізації Стратегії модернізації бухобліку та Стратегії реформування системи управління державними фінансами до більшості бухгалтерів-практиків, які працюють у держсекторі економіки, при- 
йшло розуміння того, що необхідно зосереджувати увагу не лише на контролі за витратами, адже це тривалий час превалювало в нашій діяльності, а й на підвищенні ефективності наданих послуг. Облікова інформація $є$ інформаційним джерелом для прийняття управлінських рішень. Значною мірою якість цих рішень залежить від достовірності та достатності такої інформації» [1].

\section{ВИСНОВКИ}

Отже, системна і послідовна робота, яка проводиться у сфері вдосконалення бухгалтерського обліку в державному секторі економіки України, дає можливість у найближчому майбутньому розраховувати на подальшу адаптацію законодавства країни 3 питань бухгалтерського обліку та звітності до міжнародних стандартів (IPSAS) і вдосконалення системи управління державними фінансами. Вона сприяє збільшенню прозорості даних бухгалтерського обліку та фінансової звітності в бюджетній сфері і можливості їх порівняння 3 аналогічними даними інших країн. Також існує необхідність у вирішенні проблеми більш активного здійснення вдосконалення системи підготовки та перепідготовки кадрів обліково-фінансового профілю у державному секторі, інформаційної та освітньої підтримки щодо заходів реформування обліку бюджетної сфери, а також впровадження ефективної інформаційної системи ведення бухгалтерського обліку. Саме ці заходи, як уже вказувалося, забезпечують подальший перехід на єдині методологічні засади організації бухгалтерського обліку і складання фінансової та бюджетної звітності, що дає можливість здійснювати управління державними фінансами більш прозоро та дозволяє створювати уніфіковане організаційне та інформаційне забезпечення обліку в бюджетній cфepi.

\section{Список використаних джерел}

1. Афоніна O. Реформи бухобліку в держсекторі. URL: https://uteka.ua/ua/publication/budget-13-byudzhetbuxgalterskij-uchet-otchetnost-i-kaznachejskoe-obsluzhivanie52-reformy-buxucheta-v-gossektore.

2. Бюджетний кодекс Украӥни. URL: https://zakon. rada.gov.ua/laws/show/2456-17

3. Єфименко Т.І., Бариніна М.В., Гапоненко Л.В. Реформування бухгалтерського обліку та фінансового контролю в державному секторі Украӥни: наук. метод. матеріали. К.: ДННУ «Акад. фін. Управління», 2014. С. 5-14.

4. План заходів щчодо модернізаиії системи бухгалтерського обліку в державному секторі на 2016-2018 роки: затв. наказом Міністерства фінансів Украйни від 28 лис- mопада 2016 року, № 1038. URL: https://buhgalter.com.ual zakonodavstvo/buhgalterskiy-oblik/plan-zahodiv-shchodo-

modernizatsiyi-sistemi-buhgalterskogo-obliku-v/.

5. Про схвалення Стратегії модернізації системи бухгалтерського обліку та фінансової звітності в державному секторі на період до 2025 року: схвалено розпорядженням Кабінету Міністрів Украӥни від 20 червня 2018 p. № 437-p. URL: https://zakon.rada.gov.ua/laws/main/ 437-2018-\%D1\%80.

6. Про схвалення Стратегії реформування системи управління державними фінансами на 2017-2020 роки, розпорядження Кабінету міністрів Украӥни від 8 лютого 2017 p. № 142-p. URL: http://zakon2.rada.gov.ua/laws/show/ 142-2017-\%D1\%80/paran9\#n9

7. Стратегія модернізаиії системи бухгалтерського обліку в державному секторі на 2007-2015 роки: затв. постановою Кабінету Міністрів Украӥни від 16 січня 2007p. № 34. URL: http://zakon2.rada.gov.ua/laws/show/34$2007-\% D 0 \% B F$.

\section{References}

1. Afonina O. Accounting reforms in the public sector. URL: https://uteka.ua/ua/publication/budget-13-byudzhet-

buxgalterskij-uchet-otchetnost-i-kaznachejskoe-obsluzhivanie52-reformy-buxucheta-v-gossektore. (in Ukrainian)

2. Budget Code of Ukraine URL: https://zakon.rada.gov.ua/ laws/show/2456-17 (in Ukrainian)

3. Yefymenko T.I., Barynina M.V., Haponenko L.V. Reforming accounting and financial control in the public sector of Ukraine: scientific and methodological materials. Kyiv: SESI Academy of Financial Management", 2014. pp. 5-14. (in Ukrainian)

4. Plan of measures for modernization of the accounting system in the public sector for 2016 - 2018: approved by the order of the Ministry of Finances of Ukraine from November 28, 2016, № 1038. URL: https://buhgalter.com.ua/zakonodavstvo/ buhgalterskiy-oblik/plan-zahodiv-shchodo-modernizatsiyisistemi-buhgalterskogo-obliku-v/. (in Ukrainian)

5. Approval of the strategy for modernization of the public sector accounting and financial reporting system for the period up to 2025: approved by the decree of the cabinet of ministers of Ukraine dated 20 June 2018, № 437-r. URL: https://zakon. rada.gov.ua/laws/main/437-2018-\%D1\%80. (in Ukrainian)

6. On approval of the strategy for reforming the system of public financial management for 2017-2020: ordinance of the cabinet of ministers of Ukraine of February 8, 2017, № 142-r. URL:http://zakon2.rada.gov.ua/laws/show/142-2017-

$\%$ D1\%80/paran9\#n9. (in Ukrainian)

7. Strategy for modernization of the public sector accounting system for 2007-2015: approved by the cabinet of ministers of Ukraine on January 16, 2007, № 34. URL: https://zakon2.rada.gov.ua/laws/show/34-2007-\%D0\%BF. (in Ukrainian) 